\title{
Does Financial Excess Support Land Urbanization-An Empirical Study of Cities in China
}

\author{
Zhenghui Li $^{1}{ }^{1}$, Fanqi Zou ${ }^{2}$, Yong Tan ${ }^{3}\left(\mathbb{D}\right.$ and Jinhui Zhu ${ }^{2, *(D)}$ \\ 1 Guangzhou Institute of International Finance, Guangzhou University, Guangzhou 510006, China; \\ lizh@gzhu.edu.cn \\ 2 School of Economics and Statistics, Guangzhou University, Guangzhou 510006, China; \\ 2112064099@e.gzhu.edu.cn \\ 3 Department of Accounting, Finance and Economics, Huddersfield Business School, \\ University of Huddersfield, Huddersfield, Queensgate HD1 3DH, UK; a.y.tan@hud.ac.uk \\ * Correspondence: 2112064102@e.gzhu.edu.cn
}

Citation: Li, Z.; Zou, F.; Tan, Y.; Zhu, J. Does Financial Excess Support Land Urbanization-An Empirical Study of Cities in China. Land 2021, 10, 635. https://doi.org/10.3390/ land10060635

Academic Editor: Luca Salvati

Received: 12 April 2021

Accepted: 10 June 2021

Published: 15 June 2021

Publisher's Note: MDPI stays neutral with regard to jurisdictional claims in published maps and institutional affiliations.

Copyright: () 2021 by the authors. Licensee MDPI, Basel, Switzerland. This article is an open access article distributed under the terms and conditions of the Creative Commons Attribution (CC BY) license (https:// creativecommons.org/licenses/by/ $4.0 /)$

\begin{abstract}
Most countries have experienced land urbanization, which is indispensable for financial support, especially for their financing function achievement through land appreciation and other channels in the urbanization process. By using 34 provincial capital (sub-provinces) cities in China as the sample, this paper studies the impact of finance on land urbanization construction based on the panel data from 2003 to 2018 under a differential GMM method; besides, the causes of excessive financial support and results generated on different regions are reported. Moreover, a moderate range of financial support for land urbanization is found under the influence of land finance. We obtain the following results: first, there is excessive financial support for land urbanization with regional differences exhibited; for instance, the eastern and central regions have an excessive financial support but the western region does not. Second, land urbanization with an excessive financial support correlates with financial efficiency, while the relatively large financial efficiency leads to the waste of a large number of financial resources. Third, financial support has a single and significant threshold effect on land urbanization construction, and finance has a promoting effect when land finance is less than the threshold value; otherwise, it has an inhibiting effect.
\end{abstract}

Keywords: financial support; land urbanization construction; land finance

\section{Introduction}

Finance has a far-reaching and important influence on the development of land urbanization, which influences the construction of land urbanization by reducing the transaction costs, improving the efficiency of allocation and optimizing the industrial structure. Urbanization plays a very important role in the development process of the national and local governments, and during this process land use is an essential link [1]. Land urbanization has many effects, on the one hand, it can solve the problem of population gathering to the city; on the other hand, it also solves the funding problem in the process of economic development [2]. The financial structure of the developed areas is mainly made up of three components: (1) the industry tax of urbanization within the budget; (2) revenue from land transfer out of the budget; (3) the development of real estate and construction industries. Therefore, land urbanization construction can promote financial development, which attracts more attention all over the world. However, the results of increasing financial support for land urbanization are not so perfect. Seto demonstrated that urban land expansion is slower and significantly associated with GDP growth in more developed countries than the countries with lower economic levels [3]. The reason is attributed to the fact that the urbanization of land in the developed western countries is mainly driven by seeking capital profit, and the problem of social equity cannot be solved by pursuing profit maximization. Land urbanization in China ignores the coordination 
between the internal and external factors of cities and towns. These will lead to the level of land urbanization construction likely being suppressed, although the level of financial support is increased. Therefore, there is a complex relationship between these two. How can the financial support for the construction of land urbanization ensure the result of mutual promotion? How can the level of financial support effectively promote the construction of land urbanization? Taking China as an example, Tian declared that the land ownership is changing from collective ownership to state ownership, and the government has been the dominant force in land urbanization in the process of urbanization in China [4]. In addition, urbanization in China has its characteristics due to its unique household registration system. The hukou system divided the country's population into rural (peasant) and urban (citizen) populations; at the same time, rural and urban populations enjoy different social, economic, and political rights since the founding ceremony of the People's Republic of China. Wang pointed out that the urbanization level in China has been greatly improved due to the formation of this unique urban-rural dual structure [5]. In particular, China has entered a stage of rapid urban development recently as its national strength continues to improve and its economy is growing at a rapid pace. The construction of urbanization has come into a new period from the level of less than $20 \%$ urbanization in 1971 to the level of $59 \%$ urbanization in 2018 , although the level of urbanization has not yet reached $70 \%$ in comparison with the one of the developed countries. Therefore, China has taken urbanization construction as one of the most important development strategies, and the construction of the new-type urbanization has paid more attention to sustainability and coordination [6,7]. "New-type urbanization" is a new urbanization process with the connotations of people's livelihood, sustainable development and quality, the core goal of pursuing equality, happiness, transformation, green, health and intensive, and the key content of realizing regional overall planning and coordination, industrial upgrading and low-carbon transformation, ecological civilization and intensive efficiency, and institutional reform and innovation. The new-type urbanization can affect sustainable finance, accelerate the transformation and upgrading of industry, adjust the industrial structure, and accelerate the development of modern agriculture and modern service industry [8]. To some extent, it can improve the quality of social life, promote the measures of personnel consumption and public transparency of personnel property, and encourage the expansion of private capital. How can the promotion of land urbanization be guaranteed by the level of financial support for the new-type urbanization construction proposed by China? Should the government increase or reduce the level of financial support to prevent urbanization from being suppressed? Many scholars have discussed comprehensively whether financial support is excessive in China for land urbanization construction.

The remaining structure of this paper is arranged as follows: Section 2 is the literature review. Section 3 discusses materials and methods and focuses on theoretical analysis, the research hypothesis, data collection, and model design. Section 4 conducts the empirical analysis, including the impact of financial support level on land urbanization construction, heterogeneity test, regional regression, threshold effect, and so on. Section 5 provides relevant discussions. The last part is the conclusion and includes suggestions on how the current level of financial support can properly support the construction of land urbanization.

\section{Literature Review}

\subsection{Literature Review on Promotion}

As the country's land urbanization construction has further increased with economic growth, some scholars have questioned this practice. Whether the level of financial support for land urban construction has been excessive, it may lead to the suppression of land urbanization construction. Tan argued that in many developing countries, the economy has made the level of land urbanization grow too fast, which has led to serious environmental problems and regional economic development imbalance [9]. Li asserted that some scholars believed that if economic development has led to rapid urban land expansion, social, 
economic, and ecological problems may be created; thus, it would hinder the sustainable development of urbanization [10]. Cai also denoted that a large amount of financial support for urbanization would strengthen the infrastructure construction and improve the development of the social economy, but this method also caused serious financial and debt risk [11]. Ji Yunyang et al. concluded that the efficiency of land utilization reduced during the period 2006-2015, and there was an inverted U relationship between land utilization and economic growth as finance promoted the urban expansion [12]. Besides, the excessive investment of financial resources in land urbanization would make the development of population urbanization lag behind that of the land urbanization, which would also lead to the inhibition of land urbanization [13]. Lv declared that population urbanization can lead to the expansion of land urbanization, increase the area of construction land, and that there is a close relationship between land expansion and population size change. In fact, in the process of urbanization, the intensity of financial support for land urbanization was always greater than that for population urbanization [14]. China's new urbanization plan from 2014 to 2020 mentioned that urbanization was an important engine of economic growth after industrialization; however, there was no denying that the development of population urbanization has been lagging behind the development of land urbanization as the urbanization advances $[15,16]$.

\subsection{Literature Review on Restraint}

On the contrary, some scholars have noted that the current support level from financial development has not inhibited but rather further promoted the construction of land urbanization. For example, Deng declared that economic development has played an important role in the process of urban expansion in China after understanding the extent and driving factors of urban expansion from the end of the 1980s to 2000 [17]. Daron pointed out that the main reasons of land expansion were rapid population growth, intensive agricultural development, increase in innovation of scientific and technological input, and improvement in urbanization from the perspective of sustainable land use, which was beneficial for increasing the arable land and then turning it into the construction land [18]. Potts determined that the increase in the urbanization rate has been affected by the economic development model through a longitudinal comparison of the urbanization rate and financial development in Zimbabwe and Zambia from the 1960s to the present. It also concluded that the increase of financial support was to promote rather than restrain the urbanization [19]. Liao verified that the continuous growth of China's GDP has promoted the construction of land urbanization based on the data of GlobeLand3 during 2000-2010 [20]. Cheng pointed out that land urbanization would develop fast with economic development, which was conducive to improving the residents' income and consumption ability, as well as stimulating the demand for residents, commercial and public land construction, and further promoting the urbanization process [21]. Xie analyzed the impact of land expansion for urban construction on the economy with a spatial econometric model by using a sample of 108 cities in the Yangtze River Economic Belt of China from 2005 to 2015. The results showed that land expansion not only has improved the economic growth rate but also has a spillover effect, which played a vital role in the mutual promotion of financial development and land expansion [22].

Currently, there are many controversies about the relationship between financial support and land urbanization; especially and scholars hold different opinions or perspectives on debating, which further promotes the research on the relationship. Besides, many research methods have great reference values on whether financial support promotes or restraints land urbanization. However, there are still some deficiencies. First, some issues of variable selection, model construction, and empirical methods are not suitable for dynamic panel data, and also the data is out of date, both of which lead to big errors of the empirical results. Second, why does financial support promote or restrain land urbanization? Is it caused by different stages of development or financial efficiency? Few papers have provided answers to this question. Third, there is a moderate range of financial support for 
land urbanization. The previous studies have not given an exact answer regarding whether it has this range or not. Based on these inadequacies, we cannot grasp their complex relationship; also, some results cannot be explained in the empirical research. Compared with the previous studies, the contributions of this paper are as follows: first, we are going to carry out empirical research with a differential Generalized Method of Moments (GMM) method by constructing a nonlinear model and linear model, which is beneficial for us to observe whether there is excessive support, as well as reduce the error of the intergroup heteroscedasticity that affects the experimental results in the panel data. Arellano and Blundell proposed the Generalized Method of Moments (GMM) method to estimate the regression results for dynamic panel data $[23,24]$. In the dynamic panel data, the traditional methods may lead to inaccurate results due to the issue of endogeneity, but the GMM method can solve this problem by using instrumental variables. Second, we adopt time dummy variables to study whether the reasons for promoting or inhibiting effects are caused by different stages of urbanization development; at the same time, we conduct an empirical analysis regarding the influence of finance on land urbanization construction in different regions. Thirdly, by using a threshold model, and selecting the threshold variables, we get accurate threshold values to determine the moderate range of financial support for land urbanization.

\section{Materials and Methods}

\subsection{Theoretical Analysis: The Impact of Financial Support on Land Urbanization}

As the current level of land urbanization continues to improve, the interaction between the level of financial support and its development has become more prominent. Based on this, we can make better use of the advantages of cities to promote urban construction, as well as develop the urban economy and improve people's lives. This paper is going to discuss the role of financial support in promoting land urbanization from three perspectives, including providing financial support, improving the efficiency of capital allocation, and optimizing the industrial structure.

The first one is providing financial support. Although land urbanization is a relatively complicated process of change, economic development has always been the fundamental driving force for improving the utilization rate of land, expanding the urban demand, and increasing the proportion of rural surplus labors to cities [25]. While benefiting from economic development, the further improvement of land urbanization construction has continuously increased the efficiency of urban R\&D levels, and thereby, the economic development has been promoted [26]. The development of land urbanization and economic development complement each other, but the shortage of funds for land urban construction is still an inevitable constraint. Based on the characteristics of huge input, long period, less demand elasticity, and high sunk cost for land urbanization construction, a deviation of purpose for short-term profit is produced from commercial finance, thereby creating the land urbanization construction lack of diversified capital investment. Moreover, the financing cycle of land urbanization is long, which is not in line with the characteristics of commercial finance. Therefore, the commercial finance is unwilling to involve projects related to land urbanization.

The second one is improving the efficiency of capital allocation. The effective way to improve the efficiency of capital allocation is to invest funds in the most efficient construction projects with marginal capital, which maximizes the efficiency of financial support. Firstly, the concentration and absorption of social idle funds can effectively improve the efficiency of capital allocation. Based on this, the fund owners deposit funds in financial institutions, which can not only properly keep a large number of funds, but also provide convenience for capital turnover. In this way, the efficiency of capital allocation will naturally increase. Secondly, financial institutions can invest funds in the most efficient projects with marginal capital. Compared with the individual investors, the ability of risk assessment and capital stock of financial institutions are far greater. Therefore, they play a vital role in improving the efficiency of capital allocation and provide great benefits to land 
urbanization. Finally, due to the greater social and economic risks, land urbanization over a long period may have problems of funding strand breaks. In order to solve such problems, the benefits of the project portfolio in the stock market and the insurance market can largely offset some similar risks [27]. Although the financial market may make investors lose their assets, financial institutions make it possible to minimize losses by investing in other project portfolios. Therefore, the financial support given by the financial market can effectively improve the efficiency of capital allocation.

The third one is optimizing the industrial structure. The most important effects of finance on land urbanization is to optimize the industrial structure, which can effectively promote the adjustment of industrial structure [28]. In the current process of urbanization development, financial institutions affect the upgrading and adjustment of the urbanization industry. In addition, there are four financing methods currently used in China: tax financing, land financing, local financing platform, and bank loans [29]. Land financing is an important mean to support land urbanization. By selling the land use right for a certain period of time, the local government will discount the financial revenue from the future land rental for financing the urbanization construction [30,31]. Financial institutions coordinate with multiple parties in the above financing. Financial institutions coordinate with multiple parties in the above financing. They use these capital flows, such as: guiding the relationship between market prices and funds, concentrating and allocating social idle funds, and promoting the quality of the industry by maximizing the benefits followed by fund redistribution to effectively improve the efficiency of land urbanization.

\subsection{Research Hypothesis}

The impact of finance on land urbanization is based on the above three aspects, and the provision of financial support is also a direct effect. It affects the development of urbanization in the following two ways. One way is as the carrier of urbanization, land urbanization based on infrastructure construction and real estate development is mainly manifested in the increase of the urban built-up area (land urbanization = the built-up area) [32]. Another way is that in the process of population concentration to the city, social, and economic activities are also transferred to the urban population urbanization, which is mainly manifested in the concentration of population to the city, and at the same time, people's mode of production from agriculture to the secondary and tertiary industries, and then lifestyle, behavior habits, social organization relations, and values have also changed (population urbanization $=$ influx/shift of people (from rural areas) into urban areas) [33]. Recently, excessive funds flowing to the land market and the real estate market have put too much pressure on the land urbanization construction, and a large amount of financial resources flows to the land construction, which has caused the development level of population urbanization to lag; in addition, the number of rural people migrating to the cities is not large, which has caused the phenomenon of "empty cities" [34]. According to Jin's research, the uncoordinated development of population urbanization and land urbanization would lead to a series of negative impacts on society, such as the popular phenomenon of "ghost cities" and "empty cities", and a low rate of occupancy in some development zones [35]. In addition, the excessive financial support will lead to an improvement in the greenhouse effect and environmental degradation. This process also acts on finance. According to the Environmental Kuznets Curve (EKC), the economic growth increases with the improvement in carbon emissions at the beginning. When the economy develops to a certain stage, the rise of carbon emissions inhibits economic growth. Kais and Sami used 58 countries' data to test the EKC hypothesis. They confirm the effect of an inverted U relationship between the per capita GDP and carbon dioxide emissions [36]. Therefore, China should invest more financial resources in the construction of population urbanization, which can promote land urbanization. The first hypothesis is as follows:

Hypothesis 1: Finance has over-supported land urbanization. 
Based on the condition of excessive support, we take a heterogeneity test to explore the reasons of its occurrence. China's financial intervention methods have changed since the proposals of the "New Urbanization Construction" in 2003. For example, land capitalization will lead to financial and debt risks, solving the problems of huge capital by land transferring and land mortgage. China proposed to develop a new type of urbanization at a high speed after the 18th National Congress of the CPC. However, it is currently still in the initial stage- the level of financial support cannot maximize the benefits because of the policy. Therefore, this paper puts forward that an excessive financial support may be caused by different stages of urbanization development and different policies implemented. Chen analyzed the process of urbanization by dividing the data of 110 counties and cities in China from 1960 to 2010 into three stages, namely the rapid decline stage (1960-1978), the steady rise stage (1979-1995), and the rapid improvement stage (1996-2010). Compared with other countries, China's urbanization and economic growth seem to be coordinated at a medium level. However, due to the influence of different development stages on the level of urbanization, the development of China's urbanization process has been faster than the rate of economic growth since the implementation of the "New Urbanization" in 2004. Therefore, the second hypothesis is going to be put forward as follows.

Hypothesis 2: The excessive financial support for land urbanization is caused by different stages of urbanization development.

In addition, if the result of excessive support occurs, theoretically there would be one or more suitable financial support indicators, namely finance boost land urbanization when the indicators are not exceeded, and vice versa. Hansen tested that financial constraints of 565 US companies affect investment decisions by using a dual-threshold model, and a moderate range of influence of financial constraints on investment choices is also analyzed based on the empirical results [37]. Based on the previous scholars' research on the threshold effect, we agree that a moderate range of financial support for land urbanization can be found by this method. Here is the third hypothesis as follows:

Hypothesis 3: Finance has a threshold effect in the process of supporting land urbanization.

\subsection{Variable Selection and Data Source}

\subsubsection{Independent Variable}

Most scholars have used relatively similar indicators to measure the level of land urbanization. Liu adopted the urban area to represent "the quantity of land urbanization", namely, the expansion area of urban construction land refers to the area of developed land converted into urban construction land in one year. Tiangui LV measured the land urbanization by the ratio of urbanization construction land to the total land area [14]. Yunyang Ji used a built-up area to measure the urbanization area of land [12]. Based on the above research, this paper is going to use the built-up area as the index to measure the level of land urbanization construction (area).

\subsubsection{Dependent Variable}

Gandold Smith (1969) proposed that the financial development indicator is the ratio of the total deposits and loans of banks to GDP, which is used to measure the overall financial development of a country or a region. Sun used the GDP of each province, the weighted value of the primary industry, the secondary and tertiary industries as a financial indicator when predicting the urbanization level from 2015 to 2030 [38]. In this paper, the loan-to-deposit ratio of financial institutions, that is, the ratio of deposits to loans, is selected as the indicator to measure the level of financial support(fcr). 


\subsubsection{Control Variables}

The construction of land urbanization is affected by many external factors. In order to improve the accuracy of our experiment, other influencing factors should be excluded. Based on the impact of financial support level on land urbanization, this paper selects the following control variables with reference to the studies of other scholars:

- Population agglomeration: the population density of each city (density).

- Government size: the general budget expenditure of each city (cost).

- Economic development: the per capita gross domestic product of each city(gdp).

- Industrial structure: the proportion of the secondary industry in the regional GDP (C2) and the proportion of the tertiary industry in the GDP (C3). The missing values are supplemented by linear interpolation.

\subsubsection{Threshold Variables}

When exploring whether there is a threshold effect on the impact of financial support level on land urbanization construction, this paper reviews the previous studies and then finds that land finance can be used as an appropriate threshold variable. On the one hand, land finance has a significant correlation with the indicators of financial development and land urbanization; on the other hand, as a threshold variable, land finance can better study the relationship between land urbanization construction and financial support, which can achieve stable and increasing benefits of making finance to support the level of urbanization construction. Feng analyzed the influence and contribution of land on economic growth from both theoretical and empirical perspectives, and also conducted an empirical test by using the data of 31 provinces in China from 1997 to 2004 . He also deduced a Solow model of considering land factors and analyzed the economic situation when the economy is stable. The result showed that the contribution of land finance to economic growth is significant. Therefore, we select land finance as the threshold variable to study the threshold effect [39]. Zhang selected the ratio of land transfer fee to local public budget revenue as the index of land finance. However, the local public budget revenue involves many items, which make the empirical results biased; therefore, we decide to use the land transfer fee as the index of land finance (tdcz) [40].

\subsubsection{Data Sources}

All the data used in this paper are from the statistical yearbooks of Chinese cities in municipalities directly under the central government, capitals of provinces and autonomous regions as well as developed cities (34 in total), the financial yearbooks of Chinese cities, the China Economic Network, and other public data from 2003 to 2018. Different units of data lead to inaccurate experimental results, so the level of land urbanization construction, the population density of each city, the general budget expenditure, the proportion of the secondary and tertiary industries in GDP, as well as land finance are all processed by logarithm. The descriptive statistics of various variables involved in this paper are shown in Table 1. The variable explanations are shown in Table 2.

Table 1. Descriptive statistics.

\begin{tabular}{ccccccc}
\hline Variable & Sample & Mean & Std. Dev. & Min & Median & Max \\
\hline lnarea & 544 & 5.899 & 0.626 & 4.155 & 5.963 & 7.311 \\
lfcr & 510 & 1.254 & 0.264 & 0.720 & 1.200 & 2.500 \\
lndensity & 544 & 6.313 & 0.583 & 4.820 & 6.469 & 7.730 \\
gdp & 544 & 7.144 & 4.027 & 0.967 & 6.792 & 46.775 \\
lncost & 544 & 5.699 & 1.238 & 2.496 & 5.812 & 9.030 \\
lnc2 & 544 & 3.706 & 0.229 & 2.898 & 3.742 & 4.120 \\
lnc3 & 544 & 4.018 & 0.152 & 3.636 & 4.021 & 4.394 \\
lntdcz & 544 & 14.570 & 1.189 & 8.231 & 15.132 & 18.708 \\
\hline
\end{tabular}


Table 2. Variable explanations.

\begin{tabular}{cr}
\hline Variables & Explanation \\
\hline lnarea & It represents the growth rate of land urbanization. \\
lfcr & It is the first lag in the level of financial support. \\
lndensity & It represents the growth speed about the population agglomeration \\
lncost & It represents the growth speed about the government size \\
lnc2 & It represents the growth speed about the industrial structure \\
lnc3 & It is the economic development \\
gdp & It represents the growth speed about the land finance \\
\hline lntdcz &
\end{tabular}

\subsection{Model Design}

The research objective of this paper is to test whether finance excessively supports land urbanization. Turok has discussed that there is no simple linear relationship between urbanization and economic growth, as well as between city size and productivity [41]. Therefore, in order to determine whether it is excessive, the nonlinear model (1) and linear model (2) are introduced to test Hypothesis 1:

$$
\begin{gathered}
\operatorname{area}_{i t}=\alpha_{0}+\alpha_{1} * f c r_{i t-1}^{2}+\alpha_{2} * f c r_{i t-1}+\alpha_{3} * \text { area }_{i t-1}+\sum_{j=4}^{n} \alpha_{j} * \text { Control }_{i t}+\varepsilon_{i t} \\
\text { area }_{i t}=\alpha_{0}^{\prime}+\alpha_{1}^{\prime} * f c r_{i t-1}+\alpha_{2}^{\prime} * \text { area }_{i t-1}+\sum_{j=3}^{n} \alpha_{j}^{\prime} * \text { Control }_{i t}+\varepsilon_{i t}^{\prime}
\end{gathered}
$$

Model (1) is used to explore whether finance has excessively supported land urbanization. Model (2) is used to explore whether finance has excessively supported land urbanization at the current stage. We add the criteria which use the nonlinear model to prove an excessive financial support. If the quadratic coefficient is negative, and the coefficient of the first-order term is positive, which shows that there is an "inverted U shape" relationship between financial support level and land urbanization, it shows finance excessively supported land urbanization [42]. It illustrates that an increase in the financial support will increase the land urbanization to a certain point, after which the land urbanization will start to decline [43]. Among them, area represents the level of land urbanization construction; $f c r$ means the level of financial support; $i$ is the city; $t$ is the year; $j$ denotes the types of control variables; control represents the control variables. $\alpha$ and $\alpha^{\prime}$ are regression coefficients $\varepsilon$ and $\varepsilon^{\prime}$ are the error terms. The impact of financial support on land urbanization will not have an immediate effect, so the lag period of financial support level is selected as the explanatory variable in the model. In addition, based on the fact that both models are in the process of dynamic adjustment, the current urbanization level is usually affected by the previous urbanization level; thus, the urbanization construction level will be lagged by a period.

When exploring the causes of excessive financial support, we set up a dummy variable model to test Hypothesis 2.

$$
\text { area }_{i t}=\beta_{0}+\beta_{1} * D f c r_{i t-1}+\sum_{j=2}^{n} \beta_{j} * \text { Control }_{i t}+\delta_{i t}(D=0, \text { year }<2013 ; D=1, \text { year } \geq 2013)
$$

We divide the development stage of the new-type urbanization from 2003 to 2018 into two parts: stage 1 is the development stage of the new-type urbanization from 2003 to 2012, and stage 2 is the rapid development stage of the new-type urbanization from 2013 to 2018. When $D=0, D f c r_{i t-1}$ is the financial level before 2013; When $D=1, D f c r_{i t-1}$ is the financial level in 2013 and thereafter. $\beta$ is the regression coefficients and $\delta$ is the error term. 
We use the following model to test Hypothesis 3:

$$
\text { area }_{i t}=\phi_{0}+\phi_{1} * f c r_{i t-1} I\left(q_{i t} \leq \gamma\right)+\phi_{1}^{\prime} * f c r_{i t-1} I\left(q_{i t}>\gamma\right)+\sum_{j=2}^{n} \phi_{j} * \text { Control }_{i t}+\theta_{i t}
$$

In this model (4), $q_{i t}$ is the threshold variable, $\gamma$ is the threshold value, the others are the same as the ones of model (1).

\section{Empirical Analysis and Results}

\subsection{Baseline Regression}

In this paper, the panel data of 34 cities from 2003 to 2018 is used to conduct the differential GMM estimation of model (1) by using STATA16.0 software. There are groups minus heteroscedasticity and other deviations affecting the regression results because the selected samples have the characteristics of large $\mathrm{N}$ and small $\mathrm{T}$ ( $\mathrm{N}$ represents the number of city and T represents the time of panel data from 2003-2018.). Before analyzing the effect of financial support on land urbanization, this paper needs to consider whether there are endogenous problems between finance and land urbanization [44]. Firstly, there are missing variables that affect financial support and land urbanization at the same time; that is, there is no causal relationship between financial support and land urbanization, and they are affected by the same important missing variable [45]. The reform and openingup not only promote the process of urbanization, but also improve the level of financial support; or financial support is only a reflection of future urbanization; that is, there is a reverse causal relationship between financial support and land urbanization. The higher level of land urbanization, the higher the saving rate, which will increase the level of financial support [46]. No matter which of the above relationships will produce endogenous problems and estimation bias, the OLS empirical test requires strict exogeneity between variables, so this paper intends to use the GMM model to set instrumental variables for the empirical analysis, so as to get more accurate results. The specific results are shown in Table 3:

Table 3. Regression results.

\begin{tabular}{|c|c|c|c|}
\hline & (1) & (2) & 2SLS \\
\hline & lnarea & lnarea & Lnarea \\
\hline L.lnarea & $\begin{array}{c}0.112 \\
(0.562)\end{array}$ & $\begin{array}{l}0.151 \\
(0.78)\end{array}$ & $\begin{array}{c}0.587^{* * *} \\
(7.604)\end{array}$ \\
\hline lfcr & $\begin{array}{l}0.963 * \\
(1.748)\end{array}$ & $\begin{array}{c}-0.192^{* * *} \\
(-3.69)\end{array}$ & $\begin{array}{l}-0.209 * \\
(-1.739)\end{array}$ \\
\hline lfcr 2 & $\begin{array}{l}-0.343 \text { * } \\
(-1.897)\end{array}$ & - & - \\
\hline gdp & $\begin{array}{c}0.002 \\
(1.108)\end{array}$ & $\begin{array}{c}0.001 \\
(-0.15)\end{array}$ & $\begin{array}{c}0.001 \\
(0.261)\end{array}$ \\
\hline lncost & $\begin{array}{c}0.006 \\
(0.170)\end{array}$ & $\begin{array}{c}0.051 \text { * } \\
(1.66)\end{array}$ & $\begin{array}{c}0.000 \\
(0.011)\end{array}$ \\
\hline lndensity & $\begin{array}{c}-0.049 \\
(-1.433)\end{array}$ & $\begin{array}{c}-0.060 * * \\
(-2.18)\end{array}$ & $\begin{array}{l}-0.042 * \\
(-1.671)\end{array}$ \\
\hline $\operatorname{lnc} 2$ & $\begin{array}{l}-1.856^{* *} \\
(-2.260)\end{array}$ & $\begin{array}{l}-0.118 \\
(-0.09)\end{array}$ & $\begin{array}{l}0.521 \text { * } \\
(1.889)\end{array}$ \\
\hline $\operatorname{lnc} 3$ & $\begin{array}{c}-3.178^{* * *} \\
(-2.745)\end{array}$ & $\begin{array}{l}-0.559 \\
(-0.30)\end{array}$ & $\begin{array}{c}0.390 \\
(1.072)\end{array}$ \\
\hline $\begin{array}{c}\text { Time effect } \\
\text { _cons }\end{array}$ & $\begin{array}{c}\text { YES } \\
24.871^{* * *} \\
(3.129)\end{array}$ & $\begin{array}{l}\text { YES } \\
8.566 \\
(0.71) \\
\end{array}$ & $\begin{array}{c}\text { YES } \\
0.481 \\
(0.219)\end{array}$ \\
\hline $\mathrm{N}$ & 476 & 476 & 510 \\
\hline
\end{tabular}


The regression results of the differential GMM model show that finance excessively supports land urbanization construction. In Model (1), the quadratic coefficient of financial support level is -0.343 , the regression coefficient is 0.963 and significant at the level of 0.1 , which shows that there is an "inverted U shape" relationship between financial support level and land urbanization; that is, finance first promotes land urbanization and then starts to restrain after financial support level reaches the peak. The empirical results of Model (2) show that there is a negative relationship between financial support and land urbanization at the current stage with a coefficient of -0.192 and significant at the level of 0.01, which indicates that excessive financial support has already shown up.

In order to ensure the accuracy of our results, the two-stage least square regression is selected as an alternative econometric method. We use the lagged first-order financial support as the instrumental variable. On the one hand, the lagged first-order financial support level can avoid endogenous problems when exploring the impact of financial support level on land urbanization construction; on the other hand, it can make a better comparison with the results from the differential GMM model. From Table 3, the results show that financial support has an inhibiting effect on land urbanization level at the present stage, and it is significant at the level of $5 \%$, which is consistent with the results explored in the previous differential GMM model.

\subsection{Mechanism Analysis}

\subsubsection{Mechanism Analysis}

According to the results of the differential GMM model, we find that the impact of finance on land urbanization presents an "inverted U-shaped" trend, which urges us to explore the reasons of this situation. Urbanization construction has always been one of the key projects in China. The country has been adjusting specific measures of urbanization construction based on different development stages in order to look for the most suitable measures for the current development of the country. According to different characteristics of the urbanization development stage and the development goal of the newtype urbanization, this paper divides the development stage of the new-type urbanization from 2003 to 2018 into two parts of development stage and the high-speed development stage. Due to the different strategic objectives of urbanization in different periods in China, this paper assumes that there are structural differences in different stages of urbanization. Here are the empirical results in Table 4:

Table 4. Mechanism analysis.

\begin{tabular}{ccc}
\hline & $\mathbf{D}=\mathbf{0}$ (Phase One) & $\mathbf{D}=\mathbf{1}$ (Phase Two) \\
\hline lfcr & lnarea & lnarea \\
\hline gdp & -0.119 & $0.142 *$ \\
& $(-0.931)$ & $(1.969)$ \\
lncost & $0.053^{* * *}$ & $0.006^{* *}$ \\
& $(3.354)$ & $(2.125)$ \\
lndensity & -0.072 & 0.028 \\
& $(-1.159)$ & $(0.810)$ \\
lnc2 & 0.343 & $-0.101^{* * *}$ \\
& $(1.078)$ & $(-5.146)$ \\
lnc3 & $0.911^{*}$ & -0.187 \\
& $(1.874)$ & $(-0.744)$ \\
_cons & 0.175 & -0.205 \\
& $(0.267)$ & $(-0.551)$ \\
& 1.531 & $8.7666^{* * *}$ \\
$\mathrm{~N}$ & $(0.337)$ & $(3.641)$ \\
\hline Note: ${ }^{*}{ }^{* *}$ and ${ }^{* * *}$ represent passing the significance test of $10 \%, 5 \%$ and $1 \%$, respectively.
\end{tabular}

The results in Table 4 show that the excessive financial support for land urbanization 
is not caused by different development stages. There is a negative relationship between the level of financial support in the first stage and land urbanization, and the coefficient of the explanatory variable is -0.119 but not significant. In the second stage, there is a positive relationship between financial support level and land urbanization, which is significant at the level of $10 \%$. The results show that the strategic work of China's financial support for land urbanization after the 18th National Congress of the Communist Party of China has been effective to some extent. Therefore, this paper has reasons to insist that the cause of excessive financial support for land urbanization is not caused by different stages of urbanization development.

\subsubsection{Regression Results of Different Regions}

According to different geographical locations, we divide 34 cities in China into eastern, central, and western regions in order to explore the impact of financial development on land urbanization construction in different regions.

The results of the regional regression in Table 5 show that finance in the eastern and central regions of China has excessively supported the construction of land urbanization, while is not the main affecting factor in the western region. Besides, it also shows that in the eastern and central regions, financial support has a significant inhibitory effect on land urbanization at the level of $10 \%$. The influence of financial support on land urbanization in the western area is also restrained but not significant. The inhibition effect was ranked from high to low with the central area the highest, followed by the eastern and western areas.

Table 5. Regression results of different regions.

\begin{tabular}{cccc}
\hline & Eastern Region & Central Region & Western Region \\
\hline lfcr & lnarea & lnarea & lnarea \\
\hline gdp & $-0.245^{*}$ & $-0.311^{*}$ & -0.147 \\
& $(-1.763)$ & $(-1.875)$ & $(-0.925)$ \\
lncost & $0.014^{* *}$ & $0.048^{* * *}$ & $0.045^{* * *}$ \\
& $(2.244)$ & $(3.763)$ & $(3.003)$ \\
lndensity & $0.123^{* * *}$ & $0.132 * *$ & $(2.430)$ \\
lnc2 & $(3.266)$ & $(2.608)$ & 0.066 \\
& -0.094 & 0.078 & $(0.879)$ \\
lnc3 & $(-1.254)$ & $(0.602)$ & -0.817 \\
& $2.052^{* * *}$ & -0.734 & $(-1.291)$ \\
Individual effect for city & $(5.091)$ & $(-1.007)$ & $-1.748^{*}$ \\
cons & $2.878^{* * *}$ & -1.116 & $(-1.953)$ \\
& $(5.225)$ & $(-1.191)$ & YES
\end{tabular}

\subsection{Threshold Effect Analysis}

From the above analysis, we get to know that there is an excessive financial support for the construction of land urbanization currently in China although it has been growing steadily in the past few years. This indicates that there should be a moderate range for the level of financial support to promote land urbanization to test whether there is a threshold feature for the impact of financial support on land urbanization. Based on the previous studies on the threshold effect, the threshold model of the financial support level and land urbanization construction in this paper is set in Model (3). In order to get a more accurate threshold model, we decide to take land finance as the threshold variable. In this paper, we conduct the self-sampling 300 times, and the result of the threshold numbers are tested successively in Tables 6 and 7 as follows: 
Table 6. Test of threshold values.

\begin{tabular}{cccc}
\hline & F Statistics & $p$-Value & Threshold Value \\
\hline TH-1 & $23.62 *$ & 0.087 & 10.801 \\
TH-2 & 5.66 & 0.513 & 16.1716 \\
TH-3 & 6.23 & 0.363 & 16.3949 \\
\hline
\end{tabular}

Note: ${ }^{*}$ represent passing the significance test of $10 \%$.

Table 7. Threshold model regression results.

\begin{tabular}{|c|c|}
\hline Single Threshold Test:TH-1 = 10.801 & lnarea \\
\hline lndensity & $\begin{array}{c}0.010^{* *} \\
(1.82)\end{array}$ \\
\hline Gdp & $\begin{array}{l}-0.029^{* * *} \\
(-0.70)\end{array}$ \\
\hline $\operatorname{lncost}$ & $\begin{array}{l}0.004 \\
(0.11)\end{array}$ \\
\hline $\operatorname{lnc} 2$ & $\begin{array}{l}1.504^{* * *} \\
(5.33)\end{array}$ \\
\hline $\operatorname{lnc} 3$ & $\begin{array}{c}1.395^{* * *} \\
(3.49)\end{array}$ \\
\hline $\operatorname{lfcr}(\operatorname{lntdcz}<=10.801)$ & $\begin{array}{l}0.282 * * \\
(2.10)\end{array}$ \\
\hline lfcr(lntdcz > 10.801) & $\begin{array}{l}-0.161 * \\
(-1.91)\end{array}$ \\
\hline $\begin{array}{l}\text { Time effect } \\
\text { _cons }\end{array}$ & $\begin{array}{c}\text { YES } \\
-5.092 * \\
(-1.93)\end{array}$ \\
\hline $\mathrm{N}$ & 510 \\
\hline
\end{tabular}

From Table 6, we can see the impact of financial support on land urbanization has passed the single threshold model, and the single threshold value is about 10.801 and significant at the level of 0.1 .

The results in Table 7 show that the influence of finance on land urbanization changes from promoting to inhibiting when the level of land finance is more than 10.801. The promotion effect of financial support level on land urbanization under the influence of land finance is significant at the level of $1 \%$ when land finance is less than 10.801 . The land urbanization level increases by 0.196 percentage points on average when the financial support level increases by $1 \%$. It has an inhibitory effect on land urbanization level and is significant at the level of 0.01 when the land finance is greater than 10.801 . When the level of financial support increases by $1 \%$, the land urbanization level decreases by 0.161 percentage points on average. The above indicates that there is a transition period and a threshold effect of financial support when the land finance level is 10.801; that is, financial support with a lower land finance level has a stronger effect on land urbanization construction. Finance reflects the effect of excessive support beyond the optimal level of land finance.

\section{Discussion}

\subsection{Discussion of Baseline Regression}

The financial support has an inverted $U$ relationship with land urbanization. It tells us that as the intensity of financial support increased, the speed of land urbanization also improved at the beginning. If the intensity of financial support constantly increases, it will hinder the development of land urbanization when the level of land urbanization achieved a certain standard. The reason for this result can be attributed to the regulation of China's financial system. Recently, the funds appear to flow excessively to the land market, and the real estate market in the process of urbanization construction has been 
strongly supported by the country. Under this background, the rapid development of land urbanization has restrained the urbanization level under the strong financial support. It also can be attributed to the fact that financial development provides insufficient support for population urbanization in the process of urbanization construction, which presents a sharp contrast with the excessive financial support for land urbanization. Due to the lack of financial support for the rural areas and small and medium-sized enterprises, the problem of transferring the rural population into the urban population is prominent [47]. From 2003 to 2017, the average annual expansion rate of the built-up areas reached $5.78 \%$, while the annual urban population growth rate was only $1.31 \%$. According to the housing market data in 2013, the overall vacancy rate reached $22.4 \%$, and the vacant houses were 48.98 million, which has been seriously overloaded. Dijkstra found that the urban population growth rate began to slow down or even has reversed changes by comparing the changes in urbanization, urban population, and economic growth with the European countries in the past decade. He also declared that the countryside has become more attractive because of the greater negative externalities of cities [48]. These results show that land urbanization has greatly exceeded population urbanization. The lag of population urbanization level would also hinder land urbanization construction to a certain extent in the process of land urbanization development. In addition, the reason may be that private capital is less involved in the process of urbanization construction. At present, urbanization construction and its infrastructure mostly rely on government borrowing from banks and other financial institutions. However, the government should introduce some funds from private enterprises in order to improve the efficiency of land urbanization, as well as disperse financial risks to a certain extent. In particular, China's current financial intervention is to capitalize land, because excessive accumulated financial and debt risks have no benefit for land urbanization [49].

\subsection{Discussion of Mechanism Analysis}

\subsubsection{Discussion about Mechanism Analysis}

According to the regression results in Table 4, the influence of finance on land urbanization is restrained at the present stage, but with different development stages, finance promotes land urbanization, which indicates that the reason of excessive financial support for land urbanization may be attributed to the low financial efficiency caused by the waste of a large number of financial resources. At present, although the country has given great financial support to the urbanization construction, the implementation efficiency of many measures has not reached the maximum, resulting in a large number of financial resources pouring out and considerable pressure bringing in on land urbanization construction. Moreover, there is a problem of resource waste in the process of capital flow, which affects the efficiency of land urbanization construction [50]. The number and type of financial institutions are too many, but the lack of structural optimization makes financial resources not used as they should be. In addition, the unbalanced distribution of financial institutions and financial resources leads to the lagged development of some economic regions and the insufficient utilization efficiency of financial resources. This hinders the construction of land urbanization when the country gives too much financial support.

\subsubsection{Discussion about Regression Results of Different Regions}

There are three reasons for this circumstance. The first one is most of the cities in the eastern region (totally 17 cities) have a stronger financial strength and their land development and construction have been maximized. In addition, the urbanization level in the eastern region is relatively high, so there are not too many land resources for the government to develop. Further financial support for land urbanization will not promote its level but increase its pressure. The second reason is that the central region, which has six cities, has been a key area of national development in recent years, whose aim is to catch up with some developed cities in the eastern area. Besides, the central area, which is located in the heart of China, is the smallest part among the three parts and considered as 
the hub of China's transportation and trade. In addition, the development of the central region has also overburdened the land urbanization level by the government in recent years, which showed on the table that financial support has the greatest inhibiting effect on land urbanization. The third reason is that the financial support in the western area has no significant impact on land urbanization construction. This shows that finance in the western area is not the main factor affecting land urbanization construction. The western region, which has 11 cities, is the largest region in China, they have rich land resources like the places of Xinjiang; however, compared with the other two regions, the population of the western region is relatively small, and the number of financial institutions and private enterprises is incomparable with that of the eastern and central regions. Therefore, the financial development level of the western region is low. In addition, the development of the western region is mainly focused on improving people's living standards and quality, while their economic development and urbanization should be carried out step by step, which is the main reason why financial support in the western area does not significantly affect the construction of land urbanization [51].

\subsection{Discussion of Threshold Effect Analysis}

Table 7 tells us that there is no more benefit for land urbanization when the financial support is higher. Financial support should be combined with the characteristics of land urbanization construction, rather than blindly investing funds in the construction. There is a threshold effect in the current stage, as well as an effect of diminishing marginal efficiency when the land finance level is greater than 10.801. So, 10.801 is a threshold value for land finance; below this value, the financial support level has a significant influence on land urbanization construction, which shows that the financial support in low land finance are the main factors influencing land urbanization construction. Therefore, countries with low land finance level should pay more attention to the ascension of financial support. However, the excessively high financial support level restricts land urbanization construction when the land finance level is high. This situation may depend on the following, like the excessive expansion of urbanization construction, excessive reliance on land finance, single-use of land and other problems by government, which result in the waste of a large number of common resources of the society. The purpose of land urbanization construction is to guarantee the improvement of people's living standard. Recently, the influx of rural people to the cities has made the urbanization construction unable to meet the needs of the current urban population. The most important thing is to adjust some inefficient measures immediately so that financial development can have a steady impact on urbanization construction.

\section{Conclusions and Suggestions}

Given the dynamic panel data of 34 Chinese cities from 2003 to 2018, this paper focuses on exploring the relationship between financial support and land urbanization under the premise of controlling a variety of other factors that may affect land urbanization. Compared with the theoretical arguments, this paper is targeted at analyzing whether the current financial support is excessive based on the results of the empirical analysis. In particular, the causes of excessive financial support and the moderate range of financial support are investigated deeply. Besides, based on the mechanism analysis, the regional regression and threshold effect between finance and land urbanization are estimated under the differential GMM model, and their specific influences are analyzed from the perspectives of time and space. The experimental research shows the following results: firstly, there is an excessive financial support according to Model (1); while the results of Model (2) tell that the current financial development has significantly inhibited land urbanization construction. Secondly, the results of heterogeneity test based on Model (3) indicate that the excessive financial support is not caused by the different development stages of land urbanization, but is highly likely to be the insufficient financial efficiency that restricts the development of land urbanization in China; in addition, this circumstance 
is very significant in the eastern and central regions, but unnoticeable in the western part of China. Thirdly, the empirical results based on Model (4) reveal that land finance can be used as an influencing factor of the relationship between finance and land urbanization, and there is a single and significant threshold effect with a threshold value of 10.801 when taking land finance as a threshold variable. To be specific, an increase in the finance level has a significant promoting effect on land urbanization when the level of land finance is low; while it has an inhibiting effect when the level is high.

From the above conclusions, this paper provides the following countermeasures: first, excessive finance has supported land urbanization construction currently, and this can be explained by the fact that there is a heavy reliance on financial development in the process of urbanization construction. Based on this, we should draw some financial resources from land urbanization construction, and then invest them into other advantageous projects. Due to the high level of financial support, the marginal utility of land urbanization is extremely low or even negative, so we need to adjust the efficiency of capital allocation to adapt to the current stage of China's development, for instance expanding the capital flow in order to meet the capital demand effectively and improve the quality for land urbanization construction, thus promoting the efficient combination of new urbanization construction and financial development. According to the impact of the economy on sustainable urbanization of two cities in Ghana, Anarfi Kwasi et al. mentioned that cities can create employment opportunities by making use of land for industrial construction in order to improve productivity and in turn promote economic growth [52]. Second, based on the abundant land resources, the urbanization level for the western region is not high. Therefore, they should formulate appropriate policies on strengthening the land urbanization; for instance, they have large available land area and low development costthe financial support can achieve the effect of increasing the level of land urbanization significantly by introducing more capital to strengthen the development comprehensively, which have a significant effect on the improvement of the national urbanization level. Third, adjust the role of land finance in the relationship between financial support and urbanization construction. There is a significant relationship between finance and land urbanization, and they play a great role in the influence of land urbanization construction. The excessive reliance of local governments on land finance is also one of the reasons for excessive financial support $[53,54]$. Different cities develop variously. Cities with low land finance development should be encouraged to develop land finance projects and maximize the income level to support land urbanization construction. Cities that rely excessively on land finance should reduce the development of land finance projects and use more financial resources to optimize the industrial structure. Zheng analyzed the relationship between land and finance. He declared that large-scale land financialization can offer financial support for urban construction and land development, which formed the model of investment and financing for the Chinese urban construction from the feedback of land financialization and city infrastructure investment. This model has played an important role in promoting land urbanization, ensuring the rational development and utilization of scarce land resources, speeding up the construction of land urbanization and maintaining efficient economic development [55-58].

Author Contributions: Z.L. contributed to all aspects of this work; J.Z. conducted the data analysis and wrote the main manuscript text. All authors reviewed the manuscript. All authors have read and agreed to the published version of the manuscript.

Funding: This research has been supported by 2020 Guangzhou philosophy and social science planning project (2020GZYB89).

Data Availability Statement: The data presented in this study are available on request from the author.

Conflicts of Interest: The authors declare no conflict of interest. 


\section{References}

1. Kawabata, T. Private governance schemes for green bond standard: Influence on public authorities' policy making. Green Financ. 2020, 2, 35-54. [CrossRef]

2. Vesterby, M.; Heimlich, R.E. Land Use and Demographic Change: Results from Fast-Growth Counties. Land Econ. 1991, 67, 279. [CrossRef] [PubMed]

3. Seto, K.C.; Fragkias, M.; Güneralp, B.; Reilly, M.K. A Meta-Analysis of Global Urban Land Expansion. PLoS ONE 2011, 6, e23777. [CrossRef] [PubMed]

4. Tian, L. Land use dynamics driven by rural industrialization and land finance in the peri-urban areas of China: "The examples of Jiangyin and Shunde". Land Use Policy 2015, 45, 117-127. [CrossRef]

5. Wang, X.-R.; Hui, E.C.-M.; Choguill, C.; Jia, S.-H. The new urbanization policy in China: Which way forward? Habitat Int. 2015, 47, 279-284. [CrossRef]

6. Kemfert, C.; Schmalz, S. Sustainable finance: Political challenges of development and implementation of framework conditions. Green Financ. 2019, 1, 237-248. [CrossRef]

7. Wang, Q.; Lin, J.; Zhou, K.; Fan, J.; Kwan, M.P. Does Urbanization Lead to Less Residential Energy Con-sumption? A Comparative Study of 136 Countries. Energy 2020, 202, 117765. [CrossRef]

8. Shen, L.; Zhou, J. Examining the effectiveness of indicators for guiding sustainable urbanization in China. Habitat Int. 2014, 44, 111-120. [CrossRef]

9. Tan, M.; Li, X.; Xie, H.; Lu, C. Urban Land Expansion and Arable Land Loss in China-A Case Study of Beijing-Tianjin-Hebei Region. Land Use Policy 2005, 22, 187-196. [CrossRef]

10. Li, H.; Wei, Y.H.D.; Huang, Z. Urban Land Expansion and Spatial Dynamics in Globalizing Shanghai. Sustainability 2014, 6, 8856-8875. [CrossRef]

11. Cai, Z.; Liu, Z.; Zuo, S.; Cao, S. Finding a Peaceful Road to Urbanization in China. Land Use Policy 2019, 83, 560-563. [CrossRef]

12. Ji, Y.; Guo, X.; Zhong, S.; Wu, L. Land Financialization, Uncoordinated Development of Population Urbanization and Land Urbanization, and Economic Growth: Evidence from China. Land 2020, 9, 481. [CrossRef]

13. Liu, X.; Huang, Y.; Xu, X.; Li, X.; Li, X.; Ciais, P.; Lin, P.; Gong, K.; Ziegler, A.D.; Chen, A.; et al. High-spatiotemporal-resolution mapping of global urban change from 1985 to 2015. Nat. Sustain. 2020, 3, 564-570. [CrossRef]

14. Lv, T.; Wang, L.; Zhang, X.; Xie, H.; Lu, H.; Li, H.; Liu, W.; Zhang, Y. Coupling Coordi-nated Development and Exploring Its Influencing Factors in Nanchang, China: From the Perspectives of Land Urbanization and Population Urbanization. Land 2019, 8, 178. [CrossRef]

15. Chen, S.; Jiang, J. The Relationship of Financial Development, Urbanization and Urban-Rural Income Gap: An Empirical Research Based on Provincial Panel Data in China. In Proceedings of the Ifsrap 2013-The First International Forum on Studies of Rural Areas and Peasants, Wuhan, China, 25-27 May 2014.

16. Yuan, Y.; Wang, M.; Zhu, Y.; Huang, X.; Xiong, X. Urbanization's Effects on the Urban-Rural In-come Gap in China: A MetaRegression Analysis. Land Use Policy 2020, 99, 104995. [CrossRef]

17. Deng, X.; Huang, J.; Rozelle, S.; Uchida, E. Growth, population and industrialization, and urban land expansion of China. J. Urban Econ. 2008, 63, 96-115. [CrossRef]

18. Acemoglu, D.; Aghion, P.; Bursztyn, L.; Hemous, D. The Environment and Directed Technical Change. Environ. Dir. Tech. Change 2009, 102, 131-166. [CrossRef]

19. Potts, D. Debates About African Urbanisation, Migration and Economic Growth: What Can We Learn from Zimba-bwe and Zambia? Geogr. J. 2016, 182, 251-264. [CrossRef]

20. Liao, C.; Dai, T.; Cai, H.; Zhang, W. Examining the Driving Factors Causing Rapid Urban Expansion in China: An Analysis Based on GlobeLand30 Data. ISPRS Int. J. Geo-Inf. 2017, 6, 264. [CrossRef]

21. Shu, C.; Xie, H.; Jiang, J.; Chen, Q. Is Urban Land Development Driven by Economic Development or Fiscal Revenue Stimuli in China? Land Use Policy 2018, 77, 107-115. [CrossRef]

22. Xie, H.; Zhu, Z.; Wang, B.; Liu, G.; Zhai, Q. Does the Expansion of Urban Construction Land Promote Regional Economic Growth in China? Evidence from 108 Cities in the Yangtze River Economic Belt. Sustainability 2018, 10, 4073. [CrossRef]

23. Arellano, M.; Bover, O. Another look at the instrumental variable estimation of error-components models. J. Econ. 1995, 68, 29-51. [CrossRef]

24. Blundell, R.; Bond, S. Initial Conditions and Moment Restrictions in Dynamic Panel Data Models. J. Econom. 1998, 87, 115-143. [CrossRef]

25. Chanel, O.; Delattre, L.; Napoléone, C. Determinants of Local Public Policies for Farmland Preservation and Urban Expansion: A French Illustration. Land Econ. 2014, 90, 411-433. [CrossRef]

26. Li, Z.; Liao, G.; Wang, Z.; Huang, Z. Green loan and subsidy for promoting clean production innovation. J. Clean. Prod. 2018, 187, 421-431. [CrossRef]

27. Sukharev, O.S. Structural analysis of income and risk dynamics in models of economic growth. Quant. Financ. Econ. 2020, 4, 1-18. [CrossRef]

28. Liu, Y.; Li, Z.; Xu, M. The Influential Factors of Financial Cycle Spillover: Evidence from China. Emerg. Mark. Financ. Trade 2019, 56, 1336-1350. [CrossRef] 
29. Chen, Y.; Chen, Z.; Xu, G.; Tian, Z. Built-up Land Efficiency in Urban China: Insights from the Gen-eral Land Use Plan (2006-2020). Habitat Int. 2016, 51, 31-38. [CrossRef]

30. Long, H. Land use policy in China: Introduction. Land Use Policy 2014, 40, 1-5. [CrossRef]

31. Gao, J.; Wei, Y.D.; Chen, W.; Chen, J. Economic Transition and Urban Land Expansion in Pro-vincial China. Habitat Int. 2014, 44, 461-473. [CrossRef]

32. Long, Y.; Han, H.; Tu, Y.; Shu, X. Evaluating the effectiveness of urban growth boundaries using human mobility and activity records. Cities 2015, 46, 76-84. [CrossRef]

33. Wang, L.; Li, C.C.; Ying, Q.; Cheng, X.; Wang, X.Y.; Li, X.Y.; Hu, L.Y.; Liang, L.; Yu, L.; Huang, H.B.; et al. China's Ur-ban Expansion from 1990 to 2010 Determined with Satellite Remote Sensing. Chin. Sci. Bull. 2012, 57, 2802-2812. [CrossRef]

34. Bai, X.; Chen, J.; Shi, P. Landscape Urbanization and Economic Growth in China: Positive Feedbacks and Sustainability Dilemmas. Environ. Sci. Technol. 2011, 46, 132-139. [CrossRef] [PubMed]

35. Jin, X.; Long, Y.; Sun, W.; Lu, Y.; Yang, X.; Tang, J. Evaluating cities' vitality and identifying ghost cities in China with emerging geographical data. Cities 2017, 63, 98-109. [CrossRef]

36. Kais, S.; Sami, H. An econometric study of the impact of economic growth and energy use on carbon emissions: Panel data evidence from fifty eight countries. Renew. Sustain. Energy Rev. 2016, 59, 1101-1110. [CrossRef]

37. Hansen, B.E. Threshold effects in non-dynamic panels: Estimation, testing, and inference. J. Econ. 1999, 93, 345-368. [CrossRef]

38. Sun, D.; Zhou, L.; Li, Y.; Liu, H.; Shen, X.; Wang, Z.; Wang, X. New-type urbanization in China: Predicted trends and investment demand for 2015-2030. J. Geogr. Sci. 2017, 27, 943-966. [CrossRef]

39. Feng, L. Study on the Contribution of Land Element to Economic Growth in China. China Land Sci. 2008, 22, 4-10.

40. Zhang, W.; Xu, H. Effects of land urbanization and land finance on carbon emissions: A panel data analysis for Chinese provinces. Land Use Policy 2017, 63, 493-500. [CrossRef]

41. Turok, I.; McGranahan, G. Urbanization and economic growth: The arguments and evidence for Africa and Asia. Environ. Urban. 2013, 25, 465-482. [CrossRef]

42. $\mathrm{Du}, \mathrm{D}$. The causal relationship between land urbanization quality and economic growth: Evidence from capital cities in China. Qual. Quant. 2016, 51, 2707-2723. [CrossRef]

43. Guan, X.; Wei, H.; Lu, S.; Dai, Q.; Su, H. Assessment on the urbanization strategy in China: Achievements, challenges and reflections. Habitat Int. 2018, 71, 97-109. [CrossRef]

44. Kuang, W.; Liu, J.; Dong, J.; Chi, W.; Zhang, C. The rapid and massive urban and industrial land expansions in China between 1990 and 2010: A CLUD-based analysis of their trajectories, patterns, and drivers. Landsc. Urban Plan. 2016, 145, 21-33. [CrossRef]

45. He, C.; Huang, Z.; Wang, R. Land use change and economic growth in urban China: A structural equation analysis. Urban Stud. 2014, 51, 2880-2898. [CrossRef]

46. Liu, Y.; Zhang, Z.; Zhou, Y. Efficiency of construction land allocation in China: An econometric analysis of panel data. Land Use Policy 2018, 74, 261-272. [CrossRef]

47. Gorelick, J.; Walmsley, N. The Greening of Municipal Infrastructure Investments: Technical Assistance, Instru-ments, and City Champions. Green Financ. 2020, 2, 114-134. [CrossRef]

48. Dijkstra, L.; Garcilazo, E.; McCann, P. The Economic Performance of European Cities and City Regions: Myths and Realities. Eur. Plan. Stud. 2013, 21, 334-354. [CrossRef]

49. Wu, J.; Fisher, M.; Pascual, U. Urbanization and the Viability of Local Agricultural Economies. Land Econ. 2011, 87, 109-125. [CrossRef]

50. Li, T.; Huang, Z.; Drakeford, B.M. Statistical measurement of total factor productivity under resource and environmental constraints. Natl. Account. Rev. 2019, 1, 16-27. [CrossRef]

51. Matei, I. Is Financial Development Good for Economic Growth? Empirical Insights from Emerging European Countries. Quant. Financ. Econ. 2020, 4, 653-678. [CrossRef]

52. Anarfi, K.; Hill, R.A.; Shiel, C. Highlighting the Sustainability Implications of Urbanisation: A Comparative Analysis of Two Urban Areas in Ghana. Land 2020, 9, 300. [CrossRef]

53. The World Bank; Development Research Center of the State Council. Urban. China: Toward Efficient, Inclusive, and Sustainable Urbanization; World Bank: Washington, DC, USA, 2014.

54. Li, F.; Yang, C.; Li, Z.; Failler, P. Does Geopolitics Have an Impact on Energy Trade? Empirical Research on Emerging Countries. Sustainability 2021, 13, 5199. [CrossRef]

55. Zheng, S.Q.; Sun, W.Z.; Wu, J.; Yun, W. Infrastructure Investment, Land Leasing and Real Estate Price: A Unique Financing and Investment Channel for Urban Development in Chinese Cities. Econ. Res. J. 2014, 8, 75-81.

56. Li, T.; Ma, J.; Mo, B. Does the Land Market Have an Impact on Green Total Factor Productivity? A Case Study on China. Land 2021, 10, 595. [CrossRef]

57. Yang, C.; Li, T.; Albitar, K. Does energy efficiency affect ambient PM2.5? The moderating role of energy investment. Front. Environ. Sci. 2021. [CrossRef]

58. Wang, M.; Li, Y.; Liao, G. Research on the Impact of Green Technology Innovation on Energy Total Factor Productivity-Based on Provincial Data of China. Front. Environ. Sci. 2021. [CrossRef] 